\title{
CONSUMER ATTITUDES TOWARD GENETIC TESTING AND PERSONALISED NUTRITION IN HUNGARY
}

\author{
Z. SZAKÁLY ${ }^{\mathrm{a} *}$, Zs. PolerecZKI ${ }^{\mathrm{a}}$ and S. KovÁcs ${ }^{\mathrm{b}}$ \\ ${ }^{\mathrm{a}}$ Institute of Marketing and Commerce, Faculty of Economics and Business, University of Debrecen, \\ ${ }^{\mathrm{b}}$ Institute of Sectoral Economics and Methodology, Faculty of Economics and Business, University of Debrecen, \\ H-4032 Debrecen, Böszörményi út 138. Hungary
}

(Received: 22 January 2016; accepted: 19 February 2016)

\begin{abstract}
The aim of the research is to reveal the most important influencing factors that lead to consumers' acceptance of personalised nutrition based on genetic testing. A nationwide representative questionnaire-based consumer survey was carried out involving 500 people in Hungary in 2014. The results show that consumers are divided over the new technology. Only $27.0 \%$ of the respondents have a positive attitude toward the new possibility, and they would be glad to use this new service in order to stay healthy. The rate of those who would have a genetic test because they want to follow a diet tailored to their needs is very low (16.0\%). Our result suggested that the most important factors in consumer preference on personalised nutrition are positive health message and perceived risk/benefits, gender, and educational level. The most important factors regarding the attitude toward genetic testing are easy usage, benefits, the agreement among experts, and educational level.
\end{abstract}

Keywords: consumer attitudes, genetic testing, nutrigenomics, personalized nutrition

During the past few decades there has been a surge in the number of the so-called civilization diseases worldwide, and they have been attributable to most of the deaths for a long time (Biró, 2004; Szakály, 2011). Cardiovascular diseases, diabetes, obesity, cancer, and respiratory diseases are responsible for $63 \%$ of all deaths in the whole world each year, while global diseases make up for $45.9 \%$ of them (WHO, 2004, 2014).

In the last decade, since the human genome was decoded, there has been a very fast development in the genomics technology and in the fields of science using genomic methods. The genomic researches are focusing on how the human genome interacts with the environmental factors to determine gene expression. Nutrition, as one of the most important environmental factors, has an obvious impact on health, but this impact and its mechanism are still not exactly known. A new field of science, the so-called nutrigenomics, tries to reveal the still unknown correlations. Nutrigenomics studies the influence of some components of the nutrients in the genes of certain organs on the gene expression pattern (transcriptome), on the protein content (proteome), on the post-translational modifications (one step of protein synthesis), on chromatin organization (epigenome), and on metabolites (metabolome). Accordingly, nutrigenomics is the science of how our genes enter into relations with nutrients (SzABÓ, 2013). According to HARLAND (2005), nutrigenomics studies the influence of nutrition on the level of genome, and it also applies the technology of genomics in nutrition science and in food technology. Nutrigenomics throws new light upon nutrition science (GERMAN \& Watzke, 2004; Mehrotra, 2004; Mutch et al., 2005; Kussmann \& FAY, 2008), since compared to earlier times, we can get far more information about how exposure to nutrients may lead

\footnotetext{
* To whom correspondence should be addressed. Phone: +36209681975; e-mail: szakaly.zoltan@econ.unideb.hu
} 
to diet-related diseases. Nutrigenomics helps to understand the relevant individual sensibility differences in the case of some diet-related diseases. Personalised nutrition is a conception that adapts diet, foods, and nutrients to the individual's (genetic, lifestyle and environmental) needs (KUSSMANN \& FAY, 2008).

Nutrigenomics, and its main field of application, personalised nutrition, are still so unknown among people that they have no preferences and attitudes towards them. For this reason, the most important aim of the research is to reveal the most important influencing factors that lead to people's acceptance of this new technology called personalised nutrition based on genetic testing, and that also lead to the formation of the positive consumer attitude.

\section{Materials and methods}

\subsection{Sampling}

In order to achieve the set objective, a nationwide representative questionnaire-based face-toface survey was carried out involving 500 people in Hungary in 2014. In the assigned settlements, a random walking method was used to ensure total randomness in selection. In the second step, within one household, the respondent was selected by using the so-called birthday-key method. Since the number of the female and elderly respondents was higher than the national average, the sample was corrected using multi-dimensional weighing factors (gender and age). As these methods were applied, the sample was representative of the structure of the Hungarian population in all four aspects (region, type of settlement, gender, and age). Table 1

The division of the sample according to socio-demographic variables is demonstrated in

Table 1. The socio-demographic background of the sample ( $\mathrm{N}=500)$

\begin{tabular}{lcc}
\hline & \multicolumn{2}{c}{ Division of the sample } \\
\cline { 2 - 3 } Criterion & Head & $\%$ \\
\hline Gender & 237 & 47.4 \\
Men & 263 & 52.6 \\
Women & & \\
Age & 115 & 23.0 \\
18-29 years & 98 & 19.6 \\
$30-39$ years & 94 & 18.8 \\
$40-49$ years & 122 & 24.4 \\
50-59 years & 71 & 14.2 \\
Over 60 years & & \\
Education & 53 & 10.6 \\
Elementary school & 157 & 31.4 \\
Vocational school & 200 & 40.0 \\
High school degree & 90 & 18.0 \\
University degree & & \\
Settlement & 94 & 18.8 \\
Capital city & 110 & 22.1 \\
County town & 90 & 17.9 \\
Town with more than 10000 residents & 118 & 23.6 \\
Town with between $2000-10000$ residents & 88 & 17.6 \\
Settlement with less than 2000 residents & & \\
\hline
\end{tabular}




\subsection{Questionnaire}

When making the questionnaire, two important sources of literature, which are closely connected to our researches, were used. One of them is the study of StEWART-KNOX and coworkers (2009), in which a representative survey about consumers' attitude toward and preferences for genetic testing and personalised nutrition was carried out in six European countries. Consumers were asked a question referring to consumer attitudes in the same form with the original source (STEWART-KNOX et al., 2009) in our own research as well. A further question referring to the preferences for personalised nutrition was also put to complement the content of the former question. In the research the two questions referring to preference were indicated as independent variables in RonTeLTAP's (2008) theoretical model (Fig. 1). RonTELTAP (2008) analysed consumer preferences for genetic testing and personalised nutrition based on a theoretical model created by himself (Fig. 1). This model determines different trends of consumer preferences through psychological processes evoked by factors influencing perception.

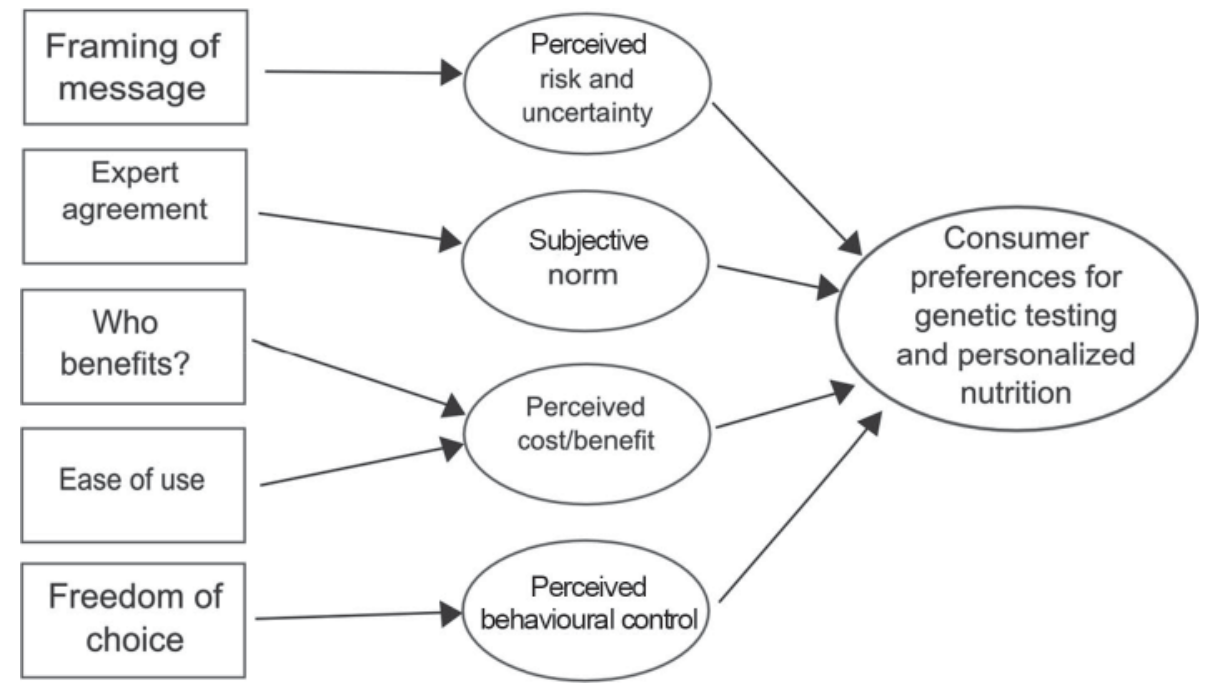

Fig. 1. Theoretical model to influence consumer preferences connected to genetic testing and personalised nutrition (Source: RONTELTAP, 2008)

\subsection{Statistical analysis}

The questionnaire data were analysed by SPSS 22.0 software. Basic statistical analysis (Kruskal-Wallis and Mann-Whitney test) and ordered factorial logit response model with proportional odds (OFLR-PO) were performed. The logit function is the natural logarithm of odds for the $\mathrm{j}$-th category, which is the importance level of consumer preference on personalized nutrition with Genetic Testing as follows. The model is defined as follows:

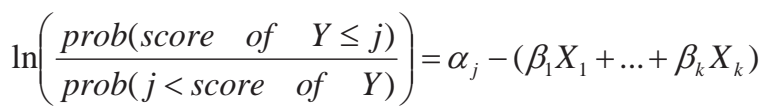


Where $\beta_{k}$ parameter of the $\mathrm{k}$-th variable, $\alpha_{j}$ threshold of the $\mathrm{j}$-th category, $\mathrm{j}$ goes from 1 to the number of the categories of $\mathrm{Y}$ minus 1 , $\mathrm{Y}$ dependent variable is the importance of personalized nutrition (first model) categorized from 1 (the less important) to 3 (the most important) and the attitude toward Genetic Testing (second model) categorized from 1 (the less likely) to 4 (the most likely), and $X_{k}$ independent variables were the factors influencing consumer perception in our questionnaires. Positive parameter values mean that when the value of the independent variable increases, the likelihood of larger value of the dependent variable increases. Negative parameter means the opposite: the likelihood of decreasing values of dependent variable increases. Impact factors of consumer perception were measured on a 1-5 scale, while psychological factors were yes/no statements. The interactions between psychological factors and factors influencing consumer perception were also built into the model. OFLR-PO has several major assumptions that have to be met. One major precondition is the lack of multicollinearity that is tested by calculating the variance inflation index (VIF). The most significant assumption is the Proportionality of odds, which means that each independent variable has an identical effect at each logarithm of odds irrespective of the split of Y. This assumption is tested by the parallel lines test.

\section{Results and discussion}

At first the consumers were made to know the conception of personalised nutrition, the content of which corresponded with the quotation published by STEWART-KNOX and coworkers (2009). "In the future it may be possible to assess your risk of developing late-onset (type 2) diabetes or heart disease with a genetic test of your saliva (by means of a mouth swab). This may allow you to eat foods that are suitable for your genetic profile. This is what is called personalised nutrition based on genetic testing."

At first the respondents were asked if they find the outlined new technological development appealing or not. The answers given to the question can be seen in Table 2 .

Table 2. Preferences for personalised nutrition among the respondents $(\mathrm{N}=500)$

\begin{tabular}{lcc}
\hline \multirow{2}{*}{$\begin{array}{l}\text { The outlined new technological development, that is personalised nutrition } \\
\text { based on genetic testing is... }\end{array}$} & \multicolumn{2}{c}{ Division of answers } \\
\cline { 2 - 3 } & Head & 27.0 \\
\hline ... an especially appealing possibility to preserve my health and I would use it. & 135 & 44.2 \\
...both appealing and not to preserve my health. & 221 & 144 \\
...not appealing at all to preserve my health and I would not use it. &
\end{tabular}

The results show that consumers are divided over the new technology. Only $27.0 \%$ of the respondents have a positive attitude toward the new possibility, and they would be glad to use this new service in order to stay healthy. The rate of the insecure people is very high, it is near $45 \%$ and they form the biggest group. For almost $30 \%$ of the respondents personalised nutrition is not appealing at all and they would not use it. 
A statistically justified correlation was searched between personalised nutrition and the demographic factors. The researches were made with the Mann-Whitney and the KruskalWallis statistical tests. Significant correlations could be found in two cases between the demographic factors and personalised nutrition. One of them is sex (Mann-Whitney $\mathrm{U}=6.81$, $\mathrm{P}=0.009$ ), the other is qualification (Kruskal-Wallis $\mathrm{K}=23.33 ; \mathrm{P}=0.001$ ). Women refuse the new technology at a much lower rate than men $(24.0 \%$, or $34.2 \%)$, that is the number of women who refuse is lower than expected. Parallel with an increase in qualification, the acceptance of the use of the new technology is also increasing significantly.

Thereinafter, four statements were drawn referring to the application willingness of genetic testing, and the respondents were expected to choose the one they mostly agree with (Table 3).

Table 3. Preferences for genetic testing among the respondents $(\mathrm{N}=500)$

\begin{tabular}{lcc}
\hline Would you personally be likely to... & \multicolumn{2}{c}{ Division of answers } \\
\cline { 2 - 3 } & Head & $\%$ \\
\hline ...have a test done specifically so that you can follow a diet tailored to your needs? & 80 & 16.0 \\
...have a test done for general interest only? & 143 & 28.6 \\
...not have a test done? & 123 & 24.6 \\
Don't know whether to have a test. & 154 & 30.8 \\
\hline
\end{tabular}

The rate of those who would have a genetic test because they want to follow a diet tailored to their needs is very low (16.0\%). Slightly more than one-fourth of the respondents $(28.6 \%)$ are interested in the test results only generally. The $24.6 \%$ of the respondents refuse genetic testing definitely, and $30.8 \%$ are insecure about the new technology.

It was also studied if there is a connection between having a genetic testing made and the different demographic factors. The Kruskal-Wallis test showed a significant difference in willingness only in the case of qualification (Kruskal-Wallis $\mathrm{K}=14.55 ; \mathrm{P}=0.002$ ). An extremely high rate of those with a university degree $(26.7 \%)$ would have a genetic testing to follow a personalised diet.

We fitted two different models (Preferences for personalised nutrition; Preferences for genetic testing) in order to analyse the importance of personalised nutrition and the attitude toward genetic testing, respectively. Both models satisfy the required assumptions regarding the measurement level of the dependent and independent variables. Parallel line tests proved the hypothesis of proportional odds indicating that the logit link function is correct (Tables 4 and 5). The Pearson Goodness of fit measure is based on the difference between the observed and predicted values. This measure has extremely large significance values, thus our models fit perfectly (Tables 4 and 5). The overall model tests show that the models without the factors (containing only the thresholds) would not be a good fit. Taking the strength of connection between the dependent variable and independent factors into consideration, the value of the Nagelkerke's $\mathrm{R}^{2}$ is sufficiently large (Tables 4 and 5). Multicollinearity is tested by calculating the VIF indices for the influential factors indicating no multicollinearity among the included factors as the largest VIF was below 2.2 in both models. 
Table 4. OFLR-PO model estimates for the importance level of consumer preference on personalised nutrition

\begin{tabular}{|c|c|c|c|}
\hline Factors & Estimates $\beta$ & Odds $\operatorname{Exp}(\beta)$ & $P$ value \\
\hline \multicolumn{4}{|l|}{ Influential factors of consumer perception } \\
\hline $\begin{array}{l}\text { Positively framed communication about personalised nutri- } \\
\text { tion: } \\
\text { Live my life in good health }\end{array}$ & 0.423 & 1.527 & 0.014 \\
\hline Agreements among experts & 0.315 & 1.370 & 0.020 \\
\hline $\begin{array}{l}\text { Freedom of choice: Genetic based nutrition should be } \\
\text { obligatory for everybody }\end{array}$ & 0.213 & 1.237 & 0.048 \\
\hline \multicolumn{4}{|l|}{ Psychological factors } \\
\hline Perceived risk* & 0.833 & 2.300 & 0.008 \\
\hline \multicolumn{4}{|l|}{ Demographic factor } \\
\hline Gender** & -1.529 & 0.217 & 0.046 \\
\hline \multicolumn{4}{|l|}{ Interactions } \\
\hline Expert agreement $\times$ credible opinion leaders* & -0.182 & 0.833 & 0.014 \\
\hline Perceived cost/benefit $* * * \times$ Educational level & 0.529 & 1.697 & 0.001 \\
\hline $\begin{array}{l}\text { freedom of choice: obligatory genetic based personalised } \\
\text { nutrition } \times \text { Perceived behavioural control* }\end{array}$ & -0.283 & 0.754 & 0.047 \\
\hline
\end{tabular}

Goodness of model fit $\left(\mathrm{Chi}^{2}=516.38 ; \mathrm{df}=583 ; \mathrm{P}=0.978\right)$; Overall model test $\left(\mathrm{Chi}^{2}=195.73 ; \mathrm{df}=11 ; \mathrm{P}<0.001\right)$; Nagelkerke pseudo R-Square (0.542); Link function: Logit, Parallel line test: $\left(\mathrm{Chi}^{2}=13.25 ; \mathrm{df}=11 ; \mathrm{P}=0.278\right)$; VIF index was under 2.2 in case of all included factors

*the reference category is "Yes"; **the reference category is "female"; ***the reference category is "No"

Odds from Table 4 show us the influential power of the dependent variables on personalised nutrition. When the odds are greater than one, the log odds are positive and the probability that personalised nutrition is of greater importance for the consumer is less than the probability that the personalized nutrition is of less importance. This situation is associated with negative parameter values. Moreover, when the odds are less than one, the log odds are negative and the interpretation is exactly the opposite.

Consumers are more likely to assign higher scores on consumer preference of personalised nutrition when they do not perceive risks, or have positively framed health communication, or think that it would be better if genetic based nutrition was obligatory for everyone, or researchers absolutely agreed on the benefits of personalised nutrition. For example, if a consumer has stronger positive message that he can live his life in a good health, the likelihood that he is interested in personalised nutrition is much higher (with 1.527 odds, the probability is approximately $53 \%$ higher, Wald $\chi^{2}(1)=6.003, \mathrm{P}=0.014$ ). If consumers do not perceive any risk, the odds are 2.3 times higher on the greater importance level of personalized nutrition than on the lower importance level (Wald $\chi^{2}(1)=6.926, \mathrm{P}=0.008$ ).

Consumers are less likely to assign higher scores on consumer preference when do not have credible opinion leaders, even if there is a consensus between the experts or do not perceive behavioural control when genetic based nutrition would be obligatory. Beside the consensus of experts, if a consumer does not have credible opinion leaders, the likelihood that he is interested in personalized nutrition is much lower (with 0.833 odds, the probability 
is approximately $17 \%$ lower compared to the case when there are credible opinion leaders, Wald $\left.\chi^{2}(1)=6.094, \mathrm{P}=0.014\right)$. Odds of female consumers considering the importance level of personalized nutrition to be too high was 4.6 times that of male consumers, a statistical significant effect, Wald $\chi^{2}(1)=3.982, \mathrm{P}=0.046$. An increase in educational level was associated with a statistically significant increase in the odds of considering the importance level of personalized nutrition too high with an odds ratio of 1.697 when perceiving the cost and benefits, Wald $\chi^{2}(1)=11.625, \mathrm{P}=0.001$.

Table 5. OFLR-PO model estimates for the attitude toward genetic testing

\begin{tabular}{|c|c|c|c|}
\hline Factors & Estimates $\beta$ & Odds $\operatorname{Exp}(\beta)$ & $P$ value \\
\hline \multicolumn{4}{|l|}{ Influential factors of consumer perception } \\
\hline Agreement among experts & 0.418 & 1.519 & 0.013 \\
\hline Ease of use: I could keep my old nutrition habits & 0.477 & 1.611 & 0.002 \\
\hline Benefits: I preserve my health & 0.476 & 1.610 & 0.001 \\
\hline \multicolumn{4}{|l|}{ Demographic factor } \\
\hline Educational level & 0.353 & 1.423 & 0.020 \\
\hline \multicolumn{4}{|l|}{ Interactions } \\
\hline $\begin{array}{l}\text { Benefits: I preserve my health } \\
\times \text { perceived cost/benefit* }\end{array}$ & -0.358 & 0.699 & $<0.001$ \\
\hline
\end{tabular}

Goodness of model fit $\left(\mathrm{Chi}^{2}=384.66 ; \mathrm{df}=415 ; \mathrm{P}=0.855\right)$; Overall model test $\left(\mathrm{Chi}^{2}=70.69 ; \mathrm{df}=5 ; \mathrm{P}<0,001\right)$; Nagelkerke pseudo R-Square (0.422); Link function: Logit, Parallel line test: $\left(\mathrm{Chi}^{2}=1.907 ; \mathrm{df}=5 ; \mathrm{P}=0.862\right)$; VIF index was under 1.4 in case of all included factors; * the reference category is "Yes"

Odds from Table 5 present us the influential power of the dependent variables on the attitude toward genetic testing. Consumers are more likely to have the genetic test done when researchers absolutely agreed on the benefits of the test or they could keep their old nutrition habits and preserve their health. For example, if a consumer is much more aware of the benefits that he can preserve his health, the likelihood that he would have the genetic test done is much higher too (with 1.610 odds, the probability is approximately $61 \%$ higher, Wald $\chi^{2}(1)=11.888, \mathrm{P}=0.001$ ). If consumers could keep their old nutrition habits, the odds are 1.611 times higher on the event of rather performing the genetic test than on the event of not performing the test, Wald $\chi^{2}(1)=10, \mathrm{P}=0.002$.

Consumers are less likely to perform the genetic test when do not perceive any advantages of the genetic testing even if they would benefit from it. For example, if a consumer does not perceive the advantages, the likelihood that he is interested in performing the test is much lower with 0.699 odds, the probability is approximately $30 \%$ lower compared to the case when perceiving the advantages, Wald $\chi^{2}(1)=19.311, \mathrm{P}<0.001$. An increase in educational level was associated with a statistically significant increase in the odds of performing the genetic test with an odds ratio of 1.423 , Wald $\chi^{2}(1)=5.370, \mathrm{P}<0.020$.

The optimal model of the consumers' preference of the new health preserving technologies is obtained by building the results demonstrated in Tables 4 and 5 in the theoretical model shown in Figure 1 (Fig. 2). 


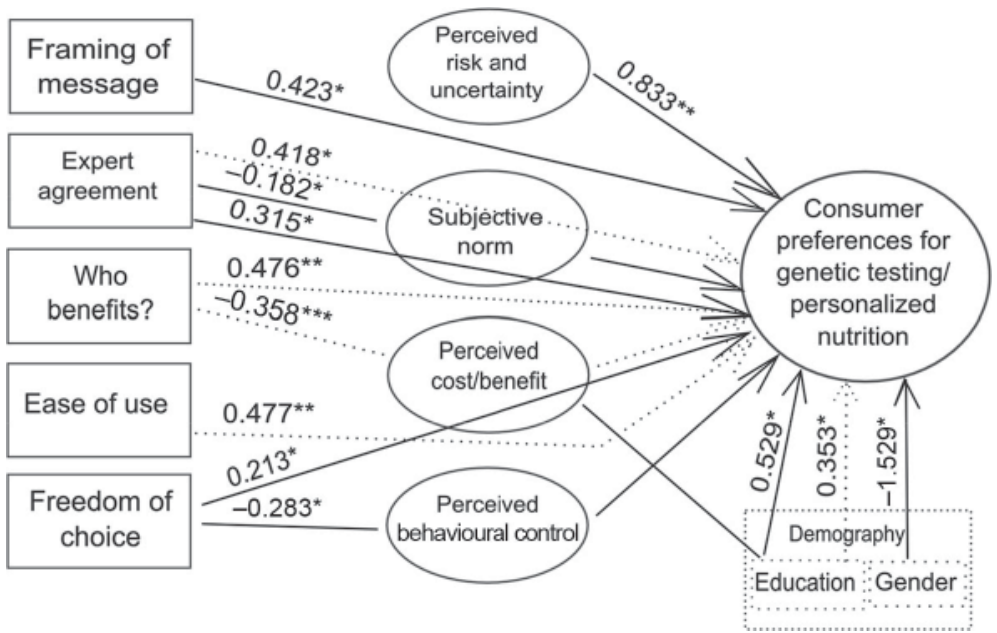

Fig. 2. Extended model to influence consumer preferences connected to personalised nutrition based on genetic testing (Source: own work based on RonTELTAP, 2008)

$* \mathrm{P}<0.05 ; * * \mathrm{P}<0.01 ; * * * \mathrm{P}<0.001$. to avoid a confusing tangle of arrows, the non-significant effects have been omitted. Numbers above the arrows represent beta estimates. Dashed arrows represent the genetic testing model and the simple arrows represent the personalised nutrition model.

From Figure 2 we can observe that the most important factors regarding the attitude toward genetic testing are easy usage (I could keep my old nutrition habits) and benefits (I preserve my health), and the agreement among experts and even the educational level do matter. The most important factors in consumer preference on personalized nutrition are positively framed communication about personalized nutrition and perceived risk and perceived costs/benefits together with educational level and gender.

\section{Conclusions}

If the results obtained during the research are compared with the data polled in the six European countries (STEWART-KNox et al., 2009), then it is obvious that willingness to make a genetic testing is the lowest in Hungary among the tested countries. For example, in Portugal $48.5 \%$ of the respondents and in France $44.3 \%$ of them would have a genetic test made because they are generally interested.

Our result suggested that the most important factors in consumer preference on personalised nutrition are positive health message and perceived risk/benefits, gender and educational level. The most important factors regarding the attitude toward genetic testing are easy usage, benefits, the agreement among experts, and educational level. Perceived uncertainty, costs and risks, freedom of choice, positive health communication did not appear to be related to genetic testing at all. Among the demographic factors only education level appeared to be related to genetic testing. The higher a consumer education level is, the more likely to have the genetic test done. Perceived uncertainty and benefits, ease of use did not appear to be related to consumer preference on personalised nutrition. Among the demographic factors only gender and education level appeared to be related to personalized nutrition. 
In case consumers do not perceive any risk, the odds are higher on the greater importance level of personalized nutrition. Consumers are less likely to assign higher scores on consumer preference when do not have credible opinion leaders, even if there is an agreement among experts. It turned out that more awareness of the benefits in preserving good health increased the likelihood of performing the genetic test. In case consumers could keep their old nutrition habits, the odds are higher on the event of rather performing the genetic test. Consumers are less likely to perform the genetic test when do not perceive any advantages of the genetic testing, even if they would benefit from it.

\section{References}

Biró, Gy. (2004): Új funkcionális élelmiszer alkotórészek - A rosszindulatú daganatok és az oxidatív degradáció. (New functional food components - Malignant tumours and oxidative degradation.) Édesipar, 50(4), 137146.

German, J.B. \& Watzke, H.J. (2004): Personalizing foods for health and delight. Compr. Rev. Food Sci. F., 3(4), $145-151$.

HARLAND, J.I. (2005): Nutrition and genetics. Mapping individual health. ILSI Concise Monograph Series. 32 p. -ref: Biró, Gy. \& (2006): Táplálkozás és genetika. Az egészség feltérképezése. Élelmiszervizsgálati közlemények, 52(1), 30-42.

Kussmann, M. \& Fay, L.B. (2008): Nutrigenomics and personalized nutrition. Pers. Med., 5(5), 447-455.

Menrotra, I. (2004): A perspective on developing and marketing food products to meet individual needs of population segments. Compr. Rev. Food Sci. F., 3(4), 142-144.

Mutch, D.M., Wahli, W. \& Williamson, G. (2005): Nutrigenomics and nutrigenetics: the emerging faces of nutrition. FASEB J., 19, 1602-1616.

Ronteltap, A. (2008): Public acceptance of nutrigenomics-based personalised nutrition. Exploring the future with experts and consumers. PhD thesis, Wageningen University, The Netherlands. 165 pages.

Stewart-Knox, B.J., Bunting, B.P., Gilpin, S., Parr, H.J., Pinhao, S., Strain, J.J., de Almeida, D.V. \& Gibney, M. (2009): Attitudes toward genetic testing and personalized nutrition in a representative sample of European consumers. Brit. J. Nutr., 101, 982-989.

SzABó, S.A. (2013): Táplálkozásgenomika a sportban. (Nutrigenomicsin sport.) Magyar sporttudományi szemle, $14(53), 40-44$.

SzakÁly, Z. (2011): Táplálkozásmarketing. (Nutrition marketing.) Mezőgazda Kiadó, Budapest. 216 pages.

WHO (2004): The global strategy on diet, physical activity and health. WHO Press, Geneva, 18 pages.

WHO (2014): World Health Statistics 2014. WHO Press, Geneva 